\title{
THE EMERGENCE OF SELF-DIRECTED WORK TEAMS AND THEIR EFFECT ON TITLE VII LAW
}

\author{
ANDREW POLLAND ${ }^{\dagger 1}$
}

\section{INTRODUCTION}

Many Fortune 1000 companies have recently implemented various forms of enhanced employee participation, often referred to as work teams or quality circles, in an effort to remain competitive in today's international economy.

During the past decade, a number of major American companies have quietly launched and nurtured self-directed work teams, and have reaped substantial rewards with little or no fanfare. Xerox, Procter \& Gamble, Tektronix, GM, Blue Cross of California, TRW, Shenandoah Life, and many others have realized the enormous power of the fully trained, fully committed team that is fully responsible for turning out a final product or service. ${ }^{2}$

This recent trend raises some rather novel issues in claims of discrimination under Title VII. ${ }^{3}$ For example, how is an African American team member supposed to prove that the team's promotion of a white male to the position of supervisor was a violation of Title VII, when the decision is inherently subjective and is ultimately formed by fifteen different people? Team decision making complicates a para-

${ }^{\dagger}$ B.S. 1997, Cornell University; J.D. Candidate 2000, University of Pennsylvania. I would like to express my appreciation to Professor Susan Sturm at the University of Pennsylvania Law School for her advice and assistance in formulating this inquiry. I would also like to thank Practice Professor Alan Lerner at the University of Pennsylvania for the time he spent reviewing and improving this Comment.

1 The inspiration for this Comment was Susan Sturm's Race, Gender, and the Law in the Twenty-First Century Workplace: Some Preliminary Observations, 1 U. PA. J. LAB. \& EMP. L. 639 (1998).

\footnotetext{
2 JACK D. ORSBURN ET AL., SELF DIRECTEd WORK TEAMS: THE NEW AMERICAN CHAIIENGE 5 (1990).

${ }^{3} 42$ U.S.C. $\$ 2000$ (1994). Title VII provides in pertinent part:

It shall be an unlawful employment practice for an employer to fail or refuse to hire or to discharge any individual, or otherwise to discriminate against any individual with respect to his compensation, terms, conditions, or privileges of employment, because of such individual's race, color, religion, sex, or national origin ....

42 U.S.C. § $2000 \mathrm{e}-2$ (a) (1).
} 
digmatic Title VII analysis because the structure of decision making differs dramatically from that which Congress envisioned when it enacted Title VII in 1964. The inherent problems associated with team decision making are beginning to surface in Title VII litigation. For example, three African American employees filed a Title VII claim in the U.S. District Court in Milwaukee, claiming that S.C. Johnson Wax's reliance on self-directed teams on the factory floor has limited African American employees' opportunity for advancement. ${ }^{4}$ This suit "appears to be the first race-bias complaint that involves work teams. "

This Comment will address the issues that arise in team-based decision making and will propose a more tenable Title VII framework for analyzing the S.C. Johnson claim and others like it. Part I will explain the impetus for the team structure and how teams generally function within American companies. Part II will discuss how a Title VII claim is analyzed under a typical hierarchical framework for both "pretext" and "mixed motive" claims as well as "disparate impact" claims. Part III will discuss the difficulty of bringing Title VII claims against subjective employment decisions under present law, and the added difficulty of applying such an analysis to team-based decisions. Additionally, Part III will explain the tenets of cognitive bias theory and will explore the dynamics of team decision making and the possible unconscious biases that can affect it. Part III will also address the shortcomings of Title VII, which presently fails to account for cognitive biases that can influence group behavior, even subconsciously. Part IV will focus on the Title VII framework for multi-input employment decisions by examining two cases that are analogous to teambased decisions. Part V will advocate changes in Title VII law to accommodate this new organizational structure in American companies. It will suggest: (1) eliminating the "Hicks" factor; (2) requiring an employer to adopt procedural safeguards to minimize evaluator bias in subjective evaluations; (3) imposing liability on employers when one evaluator takes an unlawful consideration into account when making an employment decision; and (4) allowing employees to demonstrate that an employer's reliance on the team structure in general is having a disparate impact on their employment opportunities. These changes are designed to help eliminate the present insulation from Title VII liability seemingly enjoyed by employers relying on

${ }^{4}$ See Timothy D. Schellhardt, Race-Bias Suit at S.C. Johnson Raises Some Worker-Team Issues, WALI ST. J., Feb. 13, 1997, at B7 (describing the claim filed against S.C. Johnson's team structure).

5 Id. 
subjective, group employment decisions.

\section{THE RISE OF TEAM STRUCTURES AND THEIR OPERATION IN THE FORTUNE 1000}

In order to remain competitive in the international economy, many American companies have adopted new technologies and incorporated greater flexibility in their respective production processes. ${ }^{6}$ A common means of remaining competitive has been a decreased reliance on traditional organizational structures, accompanied by a corresponding increase in reliance on bottom-up decision making. Bottom-up decision making occurs when workers are empowered with real decision-making authority regarding their everyday production tasks. "Workers are still supervised by some form of management, and the upper levels of management continue to control company policies and goals. The form and title of the revised organizational structure varies dramatically within companies, ranging from self-directed work teams ${ }^{8}$ to total quality management, ${ }^{9}$ but the central tenet remains the same in most cases: give employees greater control over the production process by eliminating formal structures of hierarchy, usually through the elimination or restructuring of middle management. ${ }^{10}$

${ }^{6}$ See Mark Barenberg, Democracy and Domination in the Law of Workplace Cooperation: From Bureaucratic to Flexible Production, 94 COLUM. L. REv. 753, 881-84 (1994) (describing the economic context of the emerging flexible work model).

${ }_{7}^{7}$ See id. at 890-903 (explaining the potential benefits of self-managed teams and their operation).

${ }^{8}$ Orsburn describes self-directed work teams as follows:

A self-directed work team is a highly trained group of employees, from 6 to 18, on average, fully responsible for turning out a well-defined segment of finished work. ... Because every member of the team shares equal responsibility for this finished segment of work, self-directed teams represent the conceptual opposite of the assembly line, where each worker assumes responsibility for a narrow technical function.

ORSBURN ET AL., supra note 2, at 8.

${ }^{9}$ Total quality management refers to an organizational theory where an employee is trained and involved in all phases of production of a particular product as opposed to performing only one aspect of the production process repeatedly. See EILEEN APPELBAUM \& ROSEMARY BATT, HIGH-PERFORMANCE WORK SYSTEMS: AMERICAN MODEIS OF WORKPLACE TRANSFORMATION 12-17 (1993) (discussing the elements of the total quality management theory that are present in American corporations).

${ }^{10}$ See ClAY CARR, TEAMPOWER: LESSONS FROM AMERIGA'S TOP COMPANIES ON PUTTING TEAMPOWER TO WORK 73-90 (1992) (describing several examples of companies that have successfully implemented team systems); ORSBURN ET AL., supra note 2, at 10 ( $[\mathrm{E}] \mathrm{Ech}$ member of a self-directed work team performs many activities, and managers leave the team alone, so long as the team's product or service meets or exceeds established expectations. ${ }^{n}$ ). 
This shift in organizational structure is designed to enable the company to produce its product at a lower cost than its competitors.

Workplace decisions are usually based on the team's consensus, and a given team may control the production process, hiring, promotions, discipline, evaluations, and layoffs. ${ }^{11}$ To ensure that team members are capable of handling these various tasks, employees receive training to improve their technical, interpersonal, and administrative skills. ${ }^{12}$ Employees operating in enhanced participatory regimes generally have more motivation on the job, lower levels of absenteeism, and greater loyalty to their employer, all of which enhance their productivity. ${ }^{13}$ In addition, such a system promotes flexibility, encourages the acceptance of new technologies, and leads to innovations in the modes of production that can improve efficiency. ${ }^{14}$

The shift towards decentralization in the production process has not been limited to traditionally blue-collar jobs. Autonomous work teams have also been effectively used for some white-collar positions. ${ }^{15}$ A 1990 study found that $47 \%$ of the Fortune 1000 are using some form of self-managing work teams, an increase from $28 \%$ in $1987 .{ }^{16}$ While many of the companies that have adopted the concept of enhanced employee participation have yet to incorporate their model throughout the company, ${ }^{17}$ the increasing number of Fortune 1000 companies experimenting with such forms of production is an em-

${ }^{11}$ See Barenberg, supra note 6, at 891 ("In its fullest forms, the self-managing team takes on personnel selection, discipline, and compensation, as well as budgeting, purchasing, and customer-relations tasks.").

12 See ORSBURN ET AL., supra note 2, at 18 (explaining the three critical areastechnical, administrative, and interpersonal-crucial to the transition to full selfdirection).

${ }^{13}$ See, e.g., Barenberg, supra note 6, at 894 (noting how participatory workplaces tend to enhance worker motivation).

${ }^{14}$ See EDWARD E. LAWLER III ET AL., EMPLOYEE INVOLVEMENT AND TOTAL QUALITY MANAGEMENT: PRACTICES AND RESULTS IN FORTUNE 1000 COMPANIES 105-12 (1992) (assessing the impact of total quality management programs); see also DALE E. YEATTS \& GLOYD HYTEN, High-PERFORMING SELF-MANAGEd WORK TEAMS: A COMPARISON OF THEORY TO PRACTICE 77-102 (1998) (discussing the positive impact that communication, cooperation, and trust within self-managed work teams can have on a firm's overall competitiveness).

${ }^{15}$ See ORSBURN ET AL., supra note 2, at 172 (noting that "[t]hree types of whitecollar self-directed work teams have in fact delivered positive benefits: (1) white-collar production teams, (2) white-collar professional teams, and (3) white-collar workers on blue-collar production teams").

${ }^{16}$ See LAWLER ET AL., supra note 14, at 28 (noting the degree to which firms have employed self-directed work teams).

${ }_{17}^{17}$ See id.; Barenberg, supra note 6, at 890 (noting that only ten percent of Fortune 1000 companies utilizing self-managed work teams "applied them to more than twenty percent of their workforce"). 
pirical indication that those that have implemented such a system have been successful in their endeavors.

Generally, an individual's performance in a self-directed work team is evaluated based on the productivity of her team. ${ }^{18}$ Such an evaluation system encourages team members to align their personal goals with that of the team. ${ }^{19}$ Professor Lawler's 1990 study found that $61 \%$ of the companies that have based their reward system on team incentives found them to be successful or very successful, while only $5 \%$ found such incentives to be unsuccessful. ${ }^{20}$ Even within the team context, however, some form of individual review exists. The most popular form of individual review is peer appraisals:

Team members are in the best position to judge other individuals on the team because of their more frequent interactions in the work area and in team meetings... Peer appraisals also help to empower teams because they are another management responsibility the team can assume with the aid of some guidelines and a good appraisal system. ${ }^{21}$

It is quite possible to imagine the potential shortcomings of a peer-review system, however, particularly if the organization's evaluation process is not designed to catch biases and prejudices among the team members. Prejudice within the group can have a devastating effect on the appraisal a particular employee receives from her peers, which in turn may negatively affect her compensation level. ${ }^{22}$ The novel aspect of the discriminatory team decision, as compared to that of a traditional prejudiced supervisor, is the difficulty in proving an allegation of discrimination due to the number of subjective evaluations that are considered in reaching the decision being challenged. An aggrieved employee in a traditional workplace, on the other hand, can more readily identify the source of potential animus when making a Title VII claim.

${ }^{18}$ See YEATTS \& HYTEN, supra note 14, at 91 (describing reward systems that are based on team performance); Barenberg, supra note 6, at 892 (noting that quality in team structures is "reinforced by the combination of group-based and individual merit pay incentives implemented widely in team plants").

${ }_{19} \mathrm{It}$ is generally agreed that if a reward system for an organization is based on team performance, "then team members will be motivated to cooperate," but when "rewards are based on individual performance, conflict is more likely to occur as team members struggle to make themselves look good, regardless of the effects of the team's overall performance." YEATTS \& HYTEN, supra note 14, at 91.

20 See LAWLER ET AL., supra note 14, at 55.

2I YEATTS \& HYTEN, supra note 14, at 128-29.

22 See $i d$. at 130 (noting that "the relationship between peer appraisals and monetary compensation lingers as a point of controversy"). 
Autonomous work teams are premised on the notion that every member of the team participates in decision making. These teams, too, have the potential for various forms of discrimination to infect the decision-making process. For example, team members may elect their supervisor from within the group. ${ }^{23}$ In addition, teams often assign members to various roles in the production process and may assign minority, older, or female employees to less desirable tasks if the team feels they are not a good "fit" with the more desirable functions in the production process. ${ }^{24}$ The majority of the team may even view an employee protected by Title VII as inferior and therefore discount that employee's suggestions, undermining the tenet of the team process. Such forms of prejudice can inhibit the performance of the team and the victimized employee, both of whom become disenchanted with the team process.

Title VII was enacted when American workplace relations could be classified as a bureaucratic hierarchy, where shop-floor employees were supervised by floor supervisors, who in turn were supervised by middle managers and so on. It is much easier to point to an invidious decision maker under the traditional paradigm of workplace relations since the contours of a supervisory relationship are better defined. With the shift toward more participatory workplace models and the blurring of formal hierarchies, a new question arises: How does a Title VII claim function in a multi-input decision-making context in light of the fact that the Title VII framework was formulated to target either one particular decision maker's bias or a company's discriminatory practices as a whole? $?^{26}$ Tangible proof of discrimination may very well be unavailable to a member of an autonomous work team, particularly when, for example, the employee has consistently been passed over for promotions based on the subjective evaluations of her peers. Does the subjective nature of such decisions and the multiple inputs into that decision insulate it from an effective Title VII analy-

${ }^{23}$ See YEATTS \& HYTEN, supra note 14, at 303 (discussing how in some cases teams have the authority to "elect their own leader with no input from management").

${ }_{24}$ See Barenberg, supra note 6, at 891 (noting that self-managed teams usually control "work-flow design, set-up, [and] task assignment").

${ }_{25}$ See YEATTS \& HYTEN, supra note 14, at 231-32 (discussing the negative effects of prejudice on team performance by lowering the quality of interpersonal interactions, and the negative impact of prejudice on the recipients of prejudice).

${ }_{26}$ See Sturm, supra note 1, at 643 ("Individuals constitute the unit of analysis, to the exclusion of groups and structures that often play more central roles in causing individual exclusion based on race and gender."). 
sis? ${ }^{27}$ Proponents of the autonomous work team model suggest creating some form of grievance procedure for team members who feel that they have been treated unfairly. ${ }^{28}$ Such a system, however, is not required by law. The issues that arise when an aggrieved employee takes legal action against her company on the basis that the terms or conditions of her employment have been hindered by the team's bias against that employee's race, gender, or national origin in violation of Title VII are intriguing and will be addressed later in this Comment.

\section{THE TITLE VII FRAMEWORK}

Title VII renders it unlawful for an employer "to fail or refuse to hire or to discharge any individual, or otherwise to discriminate against any individual with respect to his compensation, terms, conditions, or privileges of employment, because of such individual's race, color, religion, sex, or national origin. ${ }^{29}$ In pursuing a Title VII claim, a plaintiff can allege that her employer's discriminatory animus resulted in "disparate treatment" or that the employer's hiring and promotion practices have had a "disparate impact" on the opportunities afforded to a particular protected group. To prove disparate treatment, the plaintiff must demonstrate through either direct or indirect evidence that her employer considered the plaintiff's race, color, religion, sex, or national origin in making the employment decision, and that such consideration negatively impacted the terms and conditions of her employment. ${ }^{30}$ The disparate impact model is used to analyze claims of discrimination involving employment practices that are "facially neutral in their treatment of different groups but

${ }^{27}$ See Schellhardt, supra note 4, at B7 (pointing out that the Johnson-Wax suit "appears to be the first race-bias complaint that involves work teams"). An alternative theory might be that there are fewer reports of discrimination in the team context because employees are generally happier under this organizational structure and do not feel the effects of group bias. That theory, however, is undermined by recent studies that have confirmed the continued prevalence of discrimination against Hispanics and African Americans. See Linda Hamilton Krieger, Civil Rights Perestroika: Intergroup Relations After Affirmative Action, 86 CAL. L. REv. 1251, 1303 (1998) (discussing three recent studies that confirm the existence of discrimination in the labor market).

${ }_{28}$ See, e.g., ORSBURN ET AI., supra note 2, at 297 (advocating the establishment of a "Peer Disciplinary Review committee" that "broadens the application of the work-team concept within an organization").

29 U.S.C. \$ 2000e-2(a) (1) (1994).

so See Watson v. Fort Worth Bank \& Trust, 487 U.S. 977, 986 (1988) (noting that in claims of disparate treatment, "the plaintiff is required to prove that the defendant had a discriminatory intent or motiven"). 
that in fact fall more harshly on one group than another and cannot be justified by business necessity. ${ }^{, 31}$

\section{A. Disparate Treatment Theory}

Disparate treatment claims are based on the premise that the employer invidiously discriminated against the victimized plaintiff. "Under existing law, the disparate treatment plaintiff... must prove not only that she was treated differently, but that such treatment was caused by purposeful or intentional discrimination. ${ }^{, 32}$

A Title VII claim of disparate treatment falls into one of two categories: "pretext" cases and "mixed motive" cases. In a "pretext" case, the plaintiff ultimately attempts to prove that the employer's proffered reason for the plaintiff's adverse employment situation was a pretext for discrimination. ${ }^{33}$ To do so, the plaintiff must first establish a prima facie case of discrimination. If she establishes this claim, the burden of production then shifts to the employer..$^{34}$ A litigant with the burden of proof must convince the trier of fact of the validity of her position before a claim proceeds to the next stage. ${ }^{35}$ The burden of production, in contrast, is a much less onerous burden, simply requiring the litigant to offer to the trier of fact a legitimate reason for the employment decision in question. ${ }^{36}$ To establish a prima facie case of

${ }^{31}$ International Bhd. of Teamsters v. United States, 431 U.S. $324,335-36$ n.15 (1977).

${ }^{32}$ Linda Hamilton Krieger, The Content of Our Categories: A Cognitive Bias Approach to Discrimination and Equal Employment Opportunity, 47 STAN. L. REv. 1161, 1168 (1995); see also Price Waterhouse v. Hopkins, 490 U.S. 228, 241 (1989) ("The critical inquiry, the one commanded by the words of $\$ 703(a)(1)$, is whether gender was a factor in the employment decision at the moment it was made"), superseded by Civil Rights Act of 1991 § 107, Pub. L. No. 102-166 (codified at 42 U.S.C. $\$ 2000 \mathrm{e}-2(\mathrm{~m})$ (1994)) (interpreting the statutory language of Title VII in determining the appropriate legal analysis in mixed motive cases); Sturm, supra note 1, at 642 (discussing the inadequacy of present employment law because its "analysis based solely on motivation ignores the role of cognition in shaping and producing bias").

${ }^{3 s}$ See McDonnell Douglas Corp. v. Green, 411 U.S. 792, 804 (1973) (laying out the plaintiff's burden of proving pretext in claims of disparate treatment).

${ }^{34}$ See, e.g., Price Waterhouse, 490 U.S. at $245-46$ (stating that the plaintiff must first establish a prima facie case to shift the burden of production to the employer).

${ }^{35}$ See BLACK'S LAW DICTIONARY 190 (7th ed. 1999) (defining the burden of proof as "[a] party's duty to prove a disputed assertion or charge "). Thus, evidence sufficient to satisfy the burden of proof must successfully convince the factfinder of the facts sought to be established, and those facts must constitute all of the essential elements of the claim or defense.

${ }^{36}$ See id. (defining the burden of producing evidence as "a party's duty to introduce enough evidence on an issue to have the issue decided by the fact-finder rather than decided against the party in a peremptory ruling"); see also Woodson v. Scott Pa- 
discrimination under Title VII, as was established in McDonnell Douglas Corp. v. Green, a plaintiff must show: (i) that she belongs to a protected class; (ii) that she applied and was qualified for a job opening or promotion for which the employer sought applications; (iii) that despite her qualifications she was rejected; and (iv) that after her rejection, the job remained open and the employer continued to seek applicants from persons of complainant's qualifications. ${ }^{37}$ To avoid placing too heavy a burden on the plaintiff in Title VII cases involving a dispute over "subjective" qualifications, courts have required the plaintiff to demonstrate only that she was minimally qualified for a particular job until the later stages of the McDonnell test. ${ }^{38}$ The purpose of the prima facie test is to eliminate the most common, nondiscriminatory reasons behind a challenged employment decision, such as the unavailability of a job opening.

Once the plaintiff satisfies her burden of proof, a presumption of discrimination exists, and the burden of production shifts to the employer to introduce evidence of "some legitimate, non-discriminatory reason for the employee's rejection. ${ }^{, 39}$ The employer's introduction of evidence of a non-discriminatory reason for its adverse action effectively rebuts the plaintiff's prima facie case. ${ }^{40}$ Thus, once the employer satisfies its burden of production, the burden of proof shifts back to the plaintiff to convince the factfinder, by a preponderance of the evidence, that the presumptively valid reason for her rejection was in fact a pretext for a discriminatory decision. ${ }^{41}$ Even if the trier of

per Co., 109 F.3d 913, 920 n.2 (3d Cir. 1997) ("The defendant's burden at this stage is relatively light: it is satisfied if the defendant articulates any legitimate reason for the discharge; the defendant need not prove that the articulated reason actually motivated the discharge.").

${ }^{37}$ See 411 U.S. at 802 (laying out the elements required for a prima facie case of racial discrimination).

${ }^{38}$ See Ezold v. Wolf, Block, Schorr \& Solis-Cohen, 983 F.2d 509, 523 (3d Cir. 1992) ('In Title VII cases involving a dispute over 'subjective' qualifications, we have recognized that the qualification issue should often be resolved in the second and third stages of the McDonnell Douglas/Burdine analysis, to avoid putting too onerous a burden on the plaintiff...."); see also 45A AM. JUR. 2D, Job Discrimination $\$ 418$ ("While possession of objective job qualifications are an element of a plaintiff's prima facie case, the court said that evidence regarding subjective criteria should be left for the 'later stages' of the inquiry." (citing Burrus v. United Tel. Co., 683 F.2d 339, 342 (10th Cir. 1982))).

${ }_{39}$ MaDonnell Douglas Corp., 411 U.S. at 802.

${ }^{40}$ See St. Mary's Honor Ctr. v. Hicks, 509 U.S. 502, 509 (1993) (noting that once an employer has met its burden of production, it has "rebutted any legal presumption of intentional discrimination").

${ }^{41}$ See McDonnell Douglas Corp., 411 U.S. at 804 (remanding in order to provide the plaintiff an opportunity “to show that petitioner's stated reason for respondent's rejection was in fact pretext"). 
fact finds that the employer's proffered, non-discriminatory rationale was not in fact the true reason for the employment action taken, the judge may not hold the employer liable for unlawfully discriminating against the plaintiff unless the trier of fact also affirmatively finds that the employer's action was the product of unlawful discrimination. ${ }^{42}$ As stated by the Supreme Court, "nothing in law would permit us to substitute for the required finding that the employer's action was the product of unlawful discrimination, the much different (and much lesser) finding that the employer's explanation of its action was not believable. ${ }^{43}$ The holding in St Mary's Honor Center $v$. Hicks dramatically undermines the presumption of discrimination established through the prima facie test. It puts plaintiffs in pretext cases in the difficult position of having to rebut not only the employer's proffered reason for the adverse employment action, but also any other reason that the trier of fact might conceive the employer considered in taking such adverse employment action.

The legal framework for a challenged employment decision that involves a combination of both legitimate and unlawful factors, such as race, gender, or national origin (hence, a "mixed motive" case), was established in Price Waterhouse v. Hopkins. ${ }^{44}$ In a mixed motive case, the plaintiff retains the burden of persuading the finder of fact that an unlawful consideration played a part in the employment decision. ${ }^{45}$ Once the plaintiff shows that discrimination was a "motivating factor, ${ }^{, 46}$ the defendant may have a partial affirmative defense if it can

42 See Hicks, 509 U.S. at 514-15 (allowing an employer to escape liability under Title VII despite the fact that the court did not believe the employer's proffered rationale for its decision).

${ }^{43}$ Id.

44490 U.S. 228, 258 (1989) (holding that when a plaintiff in a Title VII case proves that her gender played a part in an adverse employment decision, the employer may avoid a finding of liability only by proving that it would have made the same decision without taking gender into account).

${ }^{45}$ See id. at 246 (" $[W]$ e hold that the plaintiff retains the burden of persuasion on the issue whether gender played a part in the employment decision."); see also Woodson v. Scott Paper Co., 898 F. Supp. 298, 307 (E.D. Pa. 1995) ("Plaintiff at all times has the burden of showing by a preponderance that defendant was motivated by a discriminatory purpose.").

${ }^{46} 42$ U.S.C. $\$ 2000 \mathrm{e}-2(\mathrm{~m})$ (overturning an aspect of the Price Waterhouse decision by requiring that discrimination only be a motivating factor rather than the determinative factor). The Court in Price Waterhouse defined "motivating factor" as follows:

In saying that gender played a motivating part in an employment decision, we mean that, if we asked the employer at the moment of the decision what its reasons were and if we received a truthful response, one of those reasons would be that the applicant or employee was a woman.

490 U.S. at 250. 
prove that it would have made the same decision even if it had not taken the employee's race, gender, or national origin into account in making its decision. ${ }^{47}$ Generally, plaintiffs will not know which theory they are going to submit for the jury's consideration until after discovery, and sometimes as late as closing arguments. As a result, courts permit plaintiffs to argue under both theories. ${ }^{48}$

\section{B. Disparate Impact Theory}

A plaintiff may also succeed in bringing a claim against an employer under Title VII by showing that the employer's practices, such as its hiring criteria, have had a disparate impact on members of the plaintiff's protected class. ${ }^{49}$ In such a case, the plaintiff does not need to prove discriminatory intent. ${ }^{50}$ The plaintiff, however, must identify the specific employment practice or practices that are allegedly causing the disparate impact. ${ }^{51}$ In order to establish a prima facie case of disparate impact, the plaintiff must: (1) identify a specific employment practice; (2) identify a statistically significant imbalance in the workforce adverse to the protected class; and (3) show that the spe-

${ }^{47}$ See 42 U.S.C. $\$ 2000 \mathrm{e}-2(\mathrm{~m})$ (1994) (establishing that an unlawful employment practice is the consideration of race, color, religion, sex, or national origin, as a motivating factor in making employment decisions); Price Waterhouse, 490 U.S. at 24445 (noting that if an employer would have reached the same employment decision despite the consideration of unlawful factors in making its decision, it could avoid liability).

${ }^{43}$ See FED. R. GN. P. 8(e) (2) (allowing plaintiffs to plead in the alternative); Price Waterhouse, 490 U.S. at 247 n.12 (recognizing that plaintiffs will bring claims of discrimination under both the pretext model as well as the mixed motive model).

${ }^{49}$ See Watson v. Fort Worth Bank \& Trust, 487 U.S. 977, 987 (1988) (noting that the "premise of the disparate impact approach is that some employment practices, adopted without a deliberately discriminatory motive, may in operation be functionally equivalent to intentional discrimination").

${ }^{50}$ See Washington v. Davis, 426 U.S. 229, 246-47 (1976) (stating that when an employer's hiring practices disqualify a disproportionate number of African Americans, a discriminatory purpose need not be proved); see also Connecticut v. Teal, 457 U.S. 440, 446 (1982) (same).

${ }^{51}$ In Wards Cove Packing Co. v. Atonio, the Court stated that in cases where an employer combines subjective criteria with the use of more rigid standardized rules or tests, the plaintiff is in our view responsible for isolating and identifying the specific employment practices that are allegedly responsible for any observed statistical disparities." 490 U.S. 642, 656 (1989) (quoting Watson v. Fort Worth Bank \& Trust, 487 U.S. 977,994 (1988)). This is particularly important in the present inquiry because it seems that, based on present law, a plaintiff challenging the failure of a self-directed work team to promote a minority to the position of supervisor would need to identify the specific aspects of the process which caused the alleged statistical disparity between the number of minorities qualified for the position and the number of minorities presently employed as supervisors. 
cific employment practice is responsible for the statistical disparities. ${ }^{52}$ Significant statistical disparities only based on generalized population data are insufficient to establish a prima facie case of disparate impact; the proper inquiry is a comparison between the composition of the "qualified persons in the [relevant] labor market and the persons holding at-issue jobs." ${ }^{53}$ For example, in Washington v. Davis, a group of unsuccessful African-American male applicants challenged the District of Columbia's reliance on a written personnel test to determine whether applicants possessed a particular level of verbal skill necessary for the job of police officer, arguing that the test had a racially disproportionate impact. ${ }^{54}$ Once a plaintiff has met her burden, she will have established a prima facie case of disparate impact and the burden of proof will shift to the employer to demonstrate that the challenged practice is "job related for the position in question and consistent with business necessity.,55

The plaintiff may prevail in spite of an employer's ability to demonstrate that a practice is job related and consistent with business necessity if the plaintiff can persuade the factfinder that: (i) an "alternative employment practice" will achieve the employer's legitimate interests without having a disproportionately negative impact on members of the protected classes in question, and (ii) the "respondent refuses to adopt such alternative employment practice." ${ }^{, 56}$ If the plaintiff can show that the employer can obtain a comparable result using a different practice and that the employer refuses to adopt such practice, the plaintiff will have proven that the employer's rationale is a pretext for discrimination..$^{57}$ According to the Second Circuit,

${ }^{52}$ See Watson, 487 U.S. at $994-95$ (setting forth the test for claims of disparate impact).

${ }^{53}$ Wards Cove, 490 U.S. at 650; see also Bridgeport Guardians, Inc. v. City of Bridgeport, 933 F.2d 1140, 1146 (2d Cir. 1991) ("This showing [of a prima facie case] may be made through statistical evidence revealing a disparity so great that it cannot reasonably be attributed to chance.").

${ }^{54} 426$ U.S. 229, 232-33 (1976). The claim was eventually dismissed by the Court, which held that the challenged test directly related to the requirements of the police training program and was thus job related. See id. at 250 (" [S]ome minimum verbal and communicative skill would be very useful, if not essential, to satisfactory progress in the training regime.").

${ }^{55} 42$ U.S.C. $\$ 2000 \mathrm{e}-2(\mathrm{k})(1)(\mathrm{A})$ (i) (1994).

${ }^{56} 42$ U.S.C. $\$ 2000 \mathrm{e}-2(\mathrm{k})$ (1) (A) (ii) (1999).

${ }^{57}$ See Wards Cove, 490 U.S. at 660-61 (establishing the procedure for a plaintiff to recover even when an employer proves the employment practice in question is a business necessity). This is not as viable an avenue for the plaintiff as it may first appear because the suggested alternative must be "equally effective" as the employer's practice, taking into account considerations such as cost and burden on the employer. See id. at 
"[s] uch proof would rebut a showing that the test was job related because a refusal to adopt such alternatives 'would belie a claim by [the employer] that [its] incumbent practices are being employed for nondiscriminatory reasons."

\section{The Difficulty Of APPLYING TRADITIONAL TItLE VII LAW TO SUBJECTIVE GROUP DECISION MAKING}

The Supreme Court has stated that the appropriate inquiry in a Title VII claim is whether or not an unlawful consideration "was a factor in the employment decision at the moment it was made." ${ }^{39}$ Selfdirected work teams, as discussed earlier, ${ }^{60}$ make many subjective decisions during the course of their everyday operations. Since every team member's input is taken into consideration, it is substantially more difficult to label a particular decision as discriminatory in nature because of the sheer number of decision makers involved in the ultimate course of action. The use of subjective criteria is generally more susceptible to a Title VII challenge when there are inadequate safeguards to control any bias by the evaluator. ${ }^{61}$ Such safeguards can include specific guidelines for evaluating employees with a review by higher management and the personnel division, written criteria that are reviewed with employees, an appeals process, and ratings reviewed by other supervisors. ${ }^{62}$

How may a minority worker who believes that his team has continuously passed him up for promotion based on his color prove such an allegation $?^{63}$ This Part will address this issue by illustrating the dif-

661 (emphasis added).

${ }_{53}$ Bridgeport Guardians, Inc. v. City of Bridgeport, 933 F.2d 1140, 1147 (2d Cir. 1991) (quoting Wards Cove, 490 U.S. at 661).

${ }_{59}$ Price Waterhouse v. Hopkins, 490 U.S. 228, 241 (1989), superseded by Civil Rights Act of 1991 § 107, Pub. L. No. 102-166 (codified at 42 U.S.C. 2000e-2(m)).

${ }^{60}$ See supra note 11 and accompanying text (describing the method and scope of work team decision making).

${ }^{61}$ See 45A AM. JUR. 2D, supra note 38, $\$ 419$ (discussing employer susceptibility when relying on subjective criteria without implementing safeguards).

${ }_{62}$ See Thompson v. McDonnell Douglas Corp., 416 F. Supp. 972, 982 (E.D. Mo. 1976) (upholding a rating system in which subjective criteria are evaluated in writing, discussed with the employee, and reviewed by multiple supervisors); 45A AM. JUR. 2D, supra note 38, § 419 (laying out possible safeguards to minimize bias in subjective evaluations (citing Pouncy v. Prudential Ins. Co., 499 F. Supp. 427 (S.D. Tex. 1980)). Unfortunately, controlling the potential bias of an entire team is considerably more difficult than controlling the bias of an individual evaluator and will be re-addressed in Part III.A.

${ }^{69}$ Due to the autonomy of many self-directed work teams, the potential for preju- 
ficulty in applying traditional Title VII analysis to group decision making. It will also discuss the enhanced difficulty of such an analysis when taking into account the potential for cognitive bias on the part of those making substantially subjective decisions. Many complexities surface when one applies present-day Title VII law to the team-based context prevalent in many successful corporations today. ${ }^{64}$

\section{A. Issues Raised in Performing a Disparate Treatment Analysis}

\section{Complications of Subjective, Team-Based Decisions}

Despite the Court's postponement of deciding whether a particular plaintiff is in fact "qualified" in subjective employment decisions until the last stage of the "pretext" analysis, ${ }^{65}$ several potential problems are apparent in the adjudication of a team member's disparate treatment claim.

\section{Problem 1:}

Assuming that the Court applies the prima facie threshold loosely in the group decision-making context, an employer may nonetheless respond quite easily with a legitimate, non-discriminatory reason for its decision. ${ }^{66}$ For a subjective promotion system, an employer can argue that the "subjectivity is job-related, that is, that something about the position requires the selector to use subjective evaluations of the

dice pervading the team's decision-making process is not limited to hindering a protected employee's opportunity for promotion. As mentioned above in supra notes 7-14 and accompanying text, autonomous teams control many aspects of their everyday functioning. A team that is prejudiced against a particular employee may not only fail to promote that employee to a position of authority but also may relegate that employee to more menial functions within the production process or discount that employee's suggestions, upsetting one of the essential tenets of the team-based decisionmaking process. The team may also directly affect that employee's compensation level by issuing poor evaluations and rendering harsher disciplinary sanctions upon him. Additionally, the team may simply fail to hire an individual on the basis of unlawful considerations. "Absent corrective measures, systematic biases ... can be expected to disadvantage members of stereotyped groups or individuals who are socially 'distant' from the decisionmaker or who, for whatever reason, the decisionmaker has grouped in a different cognitive category." Krieger, supra note 32, at 1207.

${ }^{64}$ This is by no means an exhaustive discussion of the complexities of such an analysis, but merely an attempt to flesh out several of the difficulties in making such an analysis.

${ }^{65}$ See supra note 38 and accompanying text (noting that in certain instances, courts will not require a plaintiff to prove that she was more than minimally qualified for a position until the later stages of the analysis).

${ }^{66}$ See 45A AM. JUR. 2D, supra note $38, \S 418$ (noting that an employer must demonstrate that the challenged subjective evaluations are necessary to the job). 
applicant's unquantifiable attributes. ${ }^{.67}$ In particular, the employer can point to the autonomy of the work team and claim that it was ultimately the team's decision. ${ }^{63}$ This is particularly difficult because the team may have taken eighteen different opinions into account in reaching its ultimate conclusion. Team-based decisions are thus distinguishable from those made by an employer basing its decision on an employee's immediate supervisor. It is much more difficult to point a finger at an individual in the former case than in the latter case, where one individual is directly responsible for the adverse decision in question.

\section{Problem 2:}

How may a plaintiff rebut the team's reasoning under the "pretext" theory when each team member may offer a different reason for the ultimate decision? It seems unfair, if not impractical, to require that a plaintiff prove that every rationale offered was pre-textual. A Title VII analysis, in its present form, however, might require just such a result since every team member in a sense acted as a decision maker and Title VII requires the examination of the motives of an individual decision maker. ${ }^{69}$ The threshold placed on the aggrieved team member is raised even higher when one includes the Hicks factor ${ }^{70}$ into the formula. Is a plaintiff supposed to attempt to persuade the factfinder that the team members' proffered justifications for their decision were pretext for discrimination, and, at the same time, attempt to undermine any other possible reason not offered that a factfinder might find compelling as well?

\section{Problem 3:}

Even if the plaintiff can prove that a team member or several team members were prejudiced against her particular demographic group, how many team members must have taken the plaintiff's race, gender, sex, or national origin into account for a court to find that the team's

${ }^{67}$ Id.

6s See supra notes 11, 23-24 and accompanying text (discussing the breadth of permitted team decisions and the ability of some self-directed work teams to elect their own supervisors without input from management).

${ }^{69}$ See Krieger, supra note 32, at 1167 ("[T]here is no discrimination without an invidiously motivated actor."); Sturm, supra note 1, at $642-43$ (noting that the laws focus on individuals "to the exclusion of groups and structures").

${ }^{70}$ See St. Mary's Honor Ctr. v. Hicks, 509 U.S. 502, 514-15 (1993) (noting that the plaintiff must still prove the employer unlawfully discriminated even if his proffered reason is determined to be pretextual); see also supra notes $42-43$ and accompanying text (discussing how a trier of fact may reject the employer's proffered rationale for its employment decision and nonetheless find that a legitimate, non-discriminatory reason for its action did in fact exist). 
proffered, non-discriminatory reason was pretextual? The factfinder at trial must decide whether discrimination was a motivating factor in the decision in question, ${ }^{71}$ or whether the same result would have been reached but for discrimination. Applying that standard, however, is not as simple as it might appear. To what extent must bias pervade the team? Is it sufficient for a minority of team members to demonstrate bias? Should a plaintiff be required to show that the team's ultimate decision would have been different in order to prove that such a justification is pretext? In the alternative, is evidence that the decision was tainted with prejudice sufficient to make such a finding?

The Third Circuit has held that if an employer makes a decision based on the recommendation of a supervisor in a traditional hierarchical organization, and if that supervisor took unlawful considerations into account in reaching its decision, that evidence is sufficient to taint the ultimate employment decision as a violation of Title VII. ${ }^{72}$ Yet, theoretically, courts could apply a different standard for teambased decisions based on the majority-vote system, since one recommendation will not directly determine an employer's decision in the same way as it would in a hierarchical system. A biased recommendation from an influential team member, however, may have as significant an effect as a biased recommendation from a supervisor in a typical organizational structure. ${ }^{73}$ Thus, courts analyzing this situation should conclude that one unchecked, biased team member is sufficient to shift the burden of proof to the employer.

\section{Cognitive Bias Theory}

Courts look to the decision maker's state of mind when he took the challenged employment action. ${ }^{74}$ Title VII has generally been

${ }^{71}$ See supra notes $45-47$ and accompanying text (laying out the legal standard in mixed motive claims).

${ }_{72}$ See, e.g., Olson v. General Elec. Astrospace, 101 F.3d 947, 954-55 (3d Cir. 1996) (averring that a reasonable factfinder could impute to GE knowledge of Olson's alleged disability on the basis of demonstrated knowledge by an employee who was part of the hiring process).

${ }^{73}$ See infra note 147 and accompanying text (discussing the potential impact of influential team members).

${ }^{74}$ See Krieger, supra note 32, at 1166-67 (discussing Title VII's shortcoming in focusing on the decision maker's state of mind); Sturm, supra note 1, at 641 ("[P] atterns of exclusion, job segregation, and bias frequently emerge from more subtle, interactive, and structural dynamics that often are not visible within the individualistic, faultdriven categories embodied in current legal structures."); see, e.g., St. Mary's Honor Ctr., 
criticized for its focus on blatant discrimination and its failure to address more subtle forms of bias. ${ }^{75}$

This failure . . . stems from the assumption that disparate treatment discrimination, whether conscious or unconscious, is primarily motivational, rather than cognitive, in origin. This one sided understanding of bias leads courts to approach every disparate treatment case as a search for discriminatory motive or intent. To the extent that intergroup bias stems from other sources, current models may either fail to identify discrimination or wrongfully attribute discriminatory motive to a wellintentioned, though biased, decision-maker. ${ }^{76}$

It is now fairly well established in social psychology that prejudice can pervade an individual's thoughts and actions subconsciously. ${ }^{77}$ This theory is based on the human brain's instinctive categorization of everything to aid in processing information: the "central premise of social cognition theory [is] that cognitive structures and processes involved in categorization and information processing can in and of themselves result in stereotyping and other forms of biased intergroup judgment previously attributed to motivational processes." ${ }^{78}$ As a result, humans unintentionally separate people by their race, gender,

509 U.S. at 516-17 ("[The plaintiff has] the ultimate burden of persuading the court that she has been the victim of intentional discrimination."); Smithers v. Bailar, 629 F.2d 892, 898 (3d Cir. 1980) (requiring plaintiff to prove that disparate treatment was caused by "purposeful or intentional discrimination").

${ }^{75}$ See, e.g., Krieger, supra note 32 , at 1164 ("Title VI jurisprudence... is inadequate to address the subtle, often unconscious forms of bias that Title VII was also intended to remedy."); Charles R. Lawrence III, The Id, the Ego, and Equal Protection: Reckoning with Unconscious Racism, 39 STAN. L. REV. 317, 321-23 (1987) (criticizing the doctrine of discriminatory purpose by focusing on the influence of unconscious racial motivation); Sturm, supra note 1, at 641-42 (pointing to recent increases in the knowledge of complex and subtle dynamics of discrimination through research in the fields of social psychology and organizational behavior).

${ }_{77}^{76}$ Krieger, supra note 32 , at 1164-65.

77 See id. at 1187-90 (hypothesizing that stereotyping is a standard cognitive function that categorizes information in a way that inherently biases perception); Krieger, supra note 27, at 1284 (stating that stereotype activation is unintentional); Lawrence, supra note 75, at 322 ("[A] large part of the behavior that produces racial discrimination is influenced by unconscious racial motivation."); Sturm, supra note 1, at 642 ("A $\mathrm{A}]$ nalysis based solely on motivation ignores the role of cognition in shaping and producing bias."). For a more thorough explanation of the origins of social cognition theory, see David L. Hamilton \& Tina K. Trolier, Stereolypes and Stereolyping: An Overview of the Cognitive Approach, in PREJUDICE, DISCRIMINATION, AND RACISM 1, 127, 133-37 (John F. Dovidio \& Samuel L. Gaertner eds., 1986).

${ }_{78}$ Krieger, supra note 32 , at 1187 . For a discussion on the cognitivists' theory of categorization, see also Lawrence, supra note 75, at 337. "All humans tend to categorize in order to make sense of experience. Too many events occur daily for us to deal successfully with each one on an individual basis; we must categorize in order to cope." Id. 
and age. ${ }^{79}$ This lack of intent severely undermines present Title VII law, which erroneously focuses on the state of mind of the decision maker at the time the employment decision is made, ${ }^{80}$ when in fact, many theorists would argue that cognitive bias distorts the decision maker's ability to form an unbiased decision well before the decision is ever made. ${ }^{81}$ Whether it is appropriate or practical for Title VII to attempt to prevent such cognitive biases is beyond the scope of this inquiry. It is, however, an additional factor to consider when advocating for the reform of Title VII law to accommodate companies' increased reliance on group decision making.

Assuming that this theory is accurate-that often, there is no single, identifiable moment of intentional discrimination-the potential for discriminatory employment decisions, particularly in the teambased context, is overwhelming and exists virtually without recourse due to the sheer number of decision makers involved in the ultimate decision. $^{82}$ Focusing on an employer's state of mind at the moment the employment decision is made fails to address unintentional biases that, according to social cognition theorists, frequently influence a decision. The potential for cognitive biases affecting an employment decision is amplified in the team-based context because it allows for additional, potentially distorted, perceptions and judgments to factor into the ultimate decision.

\section{The Potential Impact of Cognitive Bias on Subjective Group Decision Making}

Proving that a team discriminated against one of its members in failing to promote that member, or in giving her poor assignments or reviews, is dramatically complicated when one factors in cognitive bi-

${ }^{79}$ See Lawrence, supra note 75, at 330 ("[Racism] is a part of our common historical experience and, therefore, a part of our culture. It arises from the assumptions we have learned to make about the world, ourselves, and others as well as from the patterns of our fundamental social activities.").

${ }^{\text {so }}$ See Price Waterhouse v. Hopkins, 490 U.S. 228, 240-4I (1989) ("The present, active tense ... turns our attention to the actual moment of the ... adverse employment decision."), superseded by Civil Rights Act of 1991, § 107, Pub. L. No. 102-166 (codified at 42 U.S.C. $\$ 2000 \mathrm{e}-2(\mathrm{~m})(1994)$.

${ }^{81}$ See, e.g., Krieger, supra note 32, at 1211 (discussing cognitive bias and the bifurcation of perception and judgment); Lawrence, supra note 75, at 337-38 (noting the early and vulnerable age at which one learns about race).

${ }_{22}$ "The dynamics of conflict among diverse groups ... cannot be understood solely through an individualistic framework of analysis." Sturm, supra note 1, at 641-42. 
ases. ${ }^{83}$ Not only does the potential for cognitive bias undermine the entire foundation upon which present Title VII analysis is founded, but it significantly complicates the process by which an individual must prove that an employer took into account the plaintiff's race, gender, sex, or national origin in reaching his determination. After all, how may a plaintiff demonstrate bias in the employer's thought process effectively when the employer honestly believes that bias does not exist? ? $^{84}$

Thus, an individual may select a white job applicant over an equally qualified black applicant and honestly believe that this decision was based on observed intangibles unrelated to race. The employer perceives the white candidate as "more articulate," "more collegial," "more thoughtful," or "more charismatic." He is unaware of the learned stereotype that influenced his decision. ${ }^{85}$

The potential for cognitive biases to infect an individual's capacity to make a rational decision is further complicated when one considers its potentially damaging effect on group decisions. All of the issues raised in the preceding paragraphs should be reexamined for conscious as well as unconscious prejudice in each individual's decisionmaking process, and then reanalyzed in light of the effect on the team's ultimate decision. ${ }^{86}$ Such a process may not be completely realistic as a functional rule which courts can apply with any consistency,

${ }^{83}$ The court in Price Waterhouse, 490 U.S. at 235, was presented evidence that the plaintiff's pursuit of firm partnership was negatively affected by partners' cognitive biases toward women. "Thomas Beyer [the man who explained to Hopkins that the Board decided to place her candidacy for partnership on hold] advised, Hopkins should 'walk more femininely, talk more femininely, dress more femininely, wear make-up, have her hair styled, and wear jewelry.'” Id. (citation omitted). One of plaintiff's expert witnesses, a social psychologist and Associate Professor of Psychology, testified that the partnership selection process was influenced by sex stereotyping based on both the "overtly sex-based comments of partners" and "gender-neutral remarks, made by partners who knew Hopkins only slightly, that were intensely critical of her." Id.

${ }^{84}$ One of the central tenets of social cognition theory is that these biases operate absent intent or self-awareness. See Krieger, supra note 32, at 1188 ("[P] significant for present purposes, they bias a decision maker's judgment long before the 'moment of decision,' as a decision maker attends to relevant data and interprets, encodes, stores, and retrieves it from memory."). Thus, in many cases, a Title VII claim brought against an employer becomes a particularly touchy subject because the employer may honestly believe that he did not discriminate. Claims of discrimination are also resented by employers because of the terrible stigma associated with being "prejudiced" or "biased."

${ }^{85}$ Lawrence, supra note 75, at 343.

${ }^{86}$ See Krieger, supra note 32, at 1190 ("In intergroup relations, these biases, mediated through perception, inference, and judgment, can result in discrimination, whether we intend it or not, whether we know it or not."). 
but acknowledging cognitive bias in group decision making could at least provide the impetus for reformulating the present legal standard of disparate treatment. Such a course of action, as this Comment advocates in Part V, seems particularly prudent, considering the recent popularity of enhanced employee participation in many of the country's large corporations.

\section{B. Issues Raised in Performing a Disparate Impact Analysis}

The potential complications raised by applying a disparate impact standard to the group decision-making context, particularly to subjective decisions, is also quite troublesome. "A selection procedure that combines both subjective and objective criteria is generally considered subjective in nature, and, therefore, is an appropriate subject for disparate impact analysis. ${ }^{87}$

\section{Complications Raised by Claims of Disparate Impact in a Team-Based Employment System}

\section{Problem 1:}

First, the question of what constitutes the "qualified" labor market is subject to many interpretations, particularly when such a determination is largely subjective by nature. In the group context, many of the so-called qualifications for a supervisory position within the work team hinge on factors that are difficult to validate empirically. Therefore, few employer-enacted safeguards ensure that the ultimate decision was not reached arbitrarily nor by using unlawful considerations, such as race or gender. Professor Krieger has argued:

Herein lies the practical problem with applying disparate impact theory to subjective practices cases: Validating subjective decision making systems in accordance with professionally acceptable standards is neither empirically nor economically feasible, especially for jobs where intangible qualities, such as interpersonal skills, creativity, and the ability to make sound judgments under conditions of uncertainty, are critical. Accordingly, if a court applies disparate impact theory in subjective practices cases, one of two undesirable outcomes will necessarily result: either the validation requirement will be weakened or eliminated entirely, as already appears to be occurring, or its imposition will place severe and

${ }^{87}$ 45A AM. JUR. 2D, supra note 38, § 418 (citing Rose v. Wells Fargo \& Co., 902 F.2d 1417,1424 (9th Cir. 1990) ("Selection systems that combine both subjective and objective criteria are generally considered subjective in nature.")); see also Watson v. Fort Worth Bank \& Trust, 487 U.S. 977, 989 (1988) (" $[\mathrm{I}] \mathrm{t}$ is apparent that selection systems that combine both types would generally have to be considered subjective in nature."). 
ultimately unworkable burdens on small and medium-sized employers. ${ }^{88}$

\section{Problem 2:}

The ability of a plaintiff to identify the specific discriminatory practice also raises complicated issues because a plaintiff must identify exactly what aspect of the team process caused the disparate impact. ${ }^{89}$ The fact that team members may be biased against certain people may inhibit, for example, a minority's opportunity for promotion. In such a case, the plaintiff must identify what aspect of the promotion system caused the discrimination. This requirement has several implications. First, a worker is indirectly, and in some cases directly, accusing his or her peers of being prejudiced, which will not only ostracize that plaintiff from the team, but also will hurt team performance. A team-based organizational structure may be more severely impacted by employee claims than a traditional one because an employee's accusation against a supervisor within a traditional organization generally does not undermine an employer's entire operation. Second, the traditional business setting may not require a plaintiff to work closely with the accused supervisor, whereas the team model requires the efficient interaction of every member of the team in an amiable working environment. ${ }^{90}$ Finally, if an employer agrees that the team has been biased in whom it promotes and takes that power away from the team, one of the most important aspects of the team concept-its autonomy-will be disrupted.

\section{Problem 3:}

Title VII, as amended by the Civil Rights Act of 1991, shifts the burden of proof to the employer to demonstrate that "each identified discriminatory practice or practices are consistent with business necessity, including mixed subjective [and] objective procedures. ${ }^{, 91}$ When an employer considers subjective qualities in promoting its employees,

${ }^{8 s}$ Krieger, supra note 32 , at 1232.

${ }^{89}$ See supra note 51 and accompanying text (discussing the particularity requirement in establishing a prima facie case of discrimination).

${ }_{90}$ Transferring a plaintiff in the team context is not as acceptable a solution as it is in the traditional, supervisor-subordinate case. No clear job descriptions exist in selfdirected work teams due to the overlapping roles within a team. In a more traditional setting, by contrast, job roles are more clearly defined. Therefore, transferring a plaintiff to an equivalent job in the team setting is inherently more difficult because no role in two different teams will be identical. In addition, while a transferred employee in a traditional, hierarchical organization must gain the respect of his new supervisor, a transferred team member will have to earn the admiration of multiple new team members.

9I 45A AM. JUR. 2D, supra note $38, \S 418$ (footnote omitted). 
for example, the employer must prove that the subjective quality is necessary to ensure effective job performance. "In order to defend a disparate impact challenge to a subjective promotion system, an employer must present evidence that subjectivity is job-related, that is, that something about the position requires the selector to use subjective evaluations of the applicant's unquantifiable attributes. ${ }^{93}$ The rationale behind such a policy is fairly obvious:

[S] ubjective criteria are closely scrutinized by the courts, because an over-emphasis on subjective evaluations in employment decisions tends to favor incumbent workers at the expense of minorities and offers a ready mechanism for discrimination.... Elusive, purely subjective standards must give way to objectivity if statistical indicia of discrimination are to be refuted. ${ }^{94}$

Nonetheless, assuming a plaintiff succeeds in establishing that a particular practice has a disparate impact on a protected class, the aggrieved team member will still have an uphill battle to succeed in a Title VII claim. ${ }^{95}$ The employer can easily justify the particular employment practice in question by diverting the blame to the subjective determination of the team and arguing that it is necessary for the team to have province over its own management. This defense is logical and fairly convincing if one considers that a team must respect its supervisor in order to be efficient, and, presumably, the team will choose whomever it believes is the most qualified for the position. An employer that steps in and upsets a team's choice for leadership may undermine the autonomy of the team's structure, which can negatively impact employee morale, firm commitment, and overall team productivity. This scenario differs from traditional middle management decisions in which the input of subordinate employees is never sought.

In addition, unless courts require employers to demonstrate the business necessity of the team's control of the challenged action, a team decision can create further ambiguity for a court performing a disparate impact analysis. Putting that burden on employers, however, may effectively eliminate team-based decision making, which would not prove socially beneficial. How can a plaintiff formulate an

${ }^{92}$ See supra notes 66-68 and accompanying text (discussing the burden on an employer who relies on subjective criteria in defending a Title VII claim).

45A AM. JUR. 2d, supra note $38, \S 418$.

${ }_{94} I d . \$ 415$ (footnote omitted).

${ }^{95}$ See supra note 57 (noting the difficulty of contesting an employer's establishment of a legitimate business interest). 
alternative to the particular employment practice when it is the very system of group decision making that is most likely at issue in his grievance? ${ }^{96}$

2. Complications Raised in Performing a Disparate Impact Analysis of Team-Based Decisions Resulting from Cognitive Bias

When one considers the potential for cognitive bias in group decision making, performing a disparate impact analysis becomes even more complicated. For example, the "qualified" aspect of the labor pool can easily be influenced by the cognitive biases of the team members who may subconsciously rate a particular employee's ability to "lead" lower due to the color of her skin or national origin..$^{97}$ Moreover, in most team decisions, abstract skills, such as interpersonal skills or leadership abilities, are in fact determinative in the team's mind. It would be exceedingly difficult to objectify those qualities in terms of "fit" with the team to the satisfaction of a court attempting to determine the basis for a team's decision.

\section{TItLE VII CLAIMS INVOLVING STRUCTURES ANALAGOUS TO WORK TEAMS}

According to the Wall Street Journal, the suit against S.C. Johnson filed in district court in Milwaukee is the first claim challenging the team regime under Title VII. ${ }^{98}$ Cases have been reported in which plaintiffs contest an individual's employment decision made within the team context. ${ }^{99}$ It is unclear, with the prevalence of self-directed

${ }^{96}$ The Civil Rights Act of 1991 provides that in the event the plaintiff can demonstrate that "elements of a respondent's decision making process are not capable of separation for analysis, the decision making process may be analyzed as one employment practice." 42 U.S.C. $\$ 2000 \mathrm{e}-2(\mathrm{k})$ (1) (B) (i) (1994).

${ }_{97}$ See supra note 84 (discussing the impact cognitive bias can have on an individual's perception of another); see also Krieger, supra note 27, at 1294 ("[D]efining success is a subjective process subject to subtle forms of intergroup bias with which existing civil rights law has little capacity to reckon."). It could be argued that decentralized forms of decision making, like those that exist in self-directed work teams, reduce the level of prejudice and bias in the decision-making process, especially in a forum where the decision makers have a continuing relationship with one another. Assuming that such a rationale has some merit, it still fails to account for the cognitive biases among individual decision makers. Moreover, recent studies have confirmed that African-American and Hispanic men still suffer from widespread discrimination. See id. at 1303 (describing the results of three recent studies suggesting such discrimination).

${ }_{93}$ See supra note 27 (noting the novelty of the S.C. Johnson case).

${ }^{99}$ See, e.g., Hearn v. General Elec. Co., 927 F. Supp. 1486 (M.D. Ala. 1996). In 
work teams in the Fortune 1000 , why there have not been more reported claims of discrimination. One possible explanation is that workers are happier in this decentralized form of industry and do not want to "rock the boat." that the continuing relationships within work teams have helped eliminate more overt forms of discrimination. ${ }^{101}$ Finally, it is quite plausible that potential plaintiffs have been thwarted in their attempts to bring such claims by the lack of applicable precedent and by the legal community's uncertainty about how to handle such a claim. Despite the apparent shortcoming in Title VII law in this regard, there are reported cases that offer appropriate analogies and potential insights into the focus of this paper.

Woodson v. Scott Paper Co. is an example of a case in which the Third Circuit dealt with a multi-input employment decision under a Title VII "pretext analysis." 102 In Woodson, the company undertook a "company-wide reorganization of its management team." management conducted evaluations of its twenty-seven managers in order to terminate its bottom five. The only two African-American managers were ranked in the bottom five and were subsequently laid off. ${ }^{104}$ One of the terminated managers brought a Title VII suit, claiming race discrimination and retaliatory discharge. Three senior level employees performed the evaluations in question, "without interviews, and two of the three evaluators had little familiarity with the plaintiff's work." ${ }^{105}$ In addition, they had not reviewed the plaintiff's personnel file when making their decisions. The evaluators relied on both subjective and objective reasons for their decision, claiming that the plaintiff's philosophy made him an ineffective team leader and refer-

Hearm, the plaintiff challenged a plant manager's establishment of work "teams" that negatively impacted the few women previously employed in the plant. See id. at 148990. The plaintiff offered direct and circumstantial evidence of the plant manager's animus toward women in the workplace, and the court ultimately ruled in the plaintiff's favor. See id. at 1495-99, 1501 (holding that the establishment of the teams discriminated against the plaintiff). For another case in which the plaintiff initially claimed that the "team" created a hostile working environment for women but later withdrew that claim and proceeded under other theories of liability, see Reed v. A.W. Lawrence \& Co., 95 F.3d 1170 (2d Cir. 1996).

${ }^{100}$ See supra note 13 and accompanying text (noting the positive effect enhanced participation has on employee morale).

${ }_{101}$ See supra notes 8-11 and accompanying text (describing the group responsibilities of self-directed work teams).

102109 F.3d 913 (3d Cir.), cert. denied, 522 U.S. 914 (1997).

${ }^{109} 898$ F. Supp. 298,300 (E.D. Pa. 1995).

104 See id.

${ }^{105} \mathrm{Id}$. 
ring to his department's poor performance since he became its leader. ${ }^{106}$ Discrepancies between job skill ratings and the new performance ratings were supposed to be explained to the Corporate $\mathrm{Re}$ view Committee. The "discrepancy between [the plaintiff's] successful prior record of achievement and his poor ranking," however, was never raised to the Review Committee. ${ }^{107}$ The plaintiff was successful in demonstrating that two of the three evaluators knew that he had previously brought charges against the employer for discrimination in its promotion practices when they assigned to plaintiff the numerical grades that resulted in his termination. ${ }^{108}$ Plaintiff also established that one of the evaluators considered the plaintiff a "borderline insubordinate" based on his complaint to the EEOC. ${ }^{109}$ The jury returned a verdict for the plaintiff based on the theory that the "rating system used to select him for termination was pretextual."110

Woodson is helpful because it elucidates that when a group employment decision is challenged, courts are willing to inquire into how the group-in this case, the three managers performing evaluationsreached its decision. The lack of a more formalized evaluation structure and the possibility that two of the three evaluators may have been biased against the plaintiff proved dispositive. Woodson, however, is a bit unique in that there was "direct" evidence of potential animus toward the plaintiff, ${ }^{111}$ which is not generally available in suits of this nature.

The majority of cases challenging a group decision involve a "mixed motive" theory, framing the issue as whether or not the plaintiff's "race, color, religion, sex, or national origin was a motivating factor for any employment practice, even though other factors also motivated the practice. ${ }^{\text {n12 }}$ Cases involving claims of discrimination in the

${ }^{106}$ See Woodson, 109 F.3d at 918 (citing an evaluator's affidavit describing the plaintiff as "borderline insubordinate in his rejection of the organization and cultural changes" the company was trying to implement).

${ }^{107}$ Id.

${ }^{108}$ See Woodson, 898 F. Supp. at 303 (finding that "two of the evaluators ... were aware of the charges [by the plaintiff against the company] when they assigned plaintiff the numerical grades").

${ }^{109} I d$. at 304.

${ }^{110}$ Id. at 300 . The Third Circuit affirmed this part of the district court's opinion. See Woodson, 109 F.3d at 924 (" [W] e conclude that the evidence presented at trial . . . is sufficient to support a causal link between Woodson's discrimination complaints and his termination.").

111 See Woodson, 898 F. Supp. at 304 (noting an evaluator's derisive comments about the plaintiff after the plaintiff had filed his EEOC claim).

$\mathrm{f}_{12} 42$ U.S.C. $\$ 2000 \mathrm{e}-2(\mathrm{~m})$ (1994). 
academic setting are good illustrations of the application of the mixed motive theory in the context of group decision making since employment decisions in academia are generally made by the consensus of the faculty.

The plaintiff in Lam v. University of Hawaii, a woman of Vietnamese decent, brought a claim against the university alleging discrimination on the basis of her race, sex, and national origin. ${ }^{\text {II }}$ The selection of faculty members at the University of Hawaii, as at most universities, is based on a group decision by current faculty members. The appointments committee, which consists of three faculty members and two students, has the initial task of screening applicants and selecting final candidates for faculty positions. "[M]embers of the committee independently selected the 15 to 20 candidates that they considered most promising and the committee list was compiled based on these separate lists." ${ }^{\text {114 }}$ The entire fifteen-person faculty then debated and voted on the finalists. "The hiring process is ... not insulated from the illegitimate biases of faculty members. Indeed, since the faculty is small-only fifteen members-and great emphasis is placed on collegiality and consensus decision making, even a single person's biases may be relatively influential." ${ }^{\text {"15 }}$ The plaintiff alleged that she was discriminated against based on impermissible considerations under Title VII. To validate her claim, Lam pointed to evidence that one member of the appointments committee was biased against women and Asians. ${ }^{116}$ She also showed that another male faculty member stated that the position should be filled by a male. ${ }^{117}$

The Ninth Circuit moved away from the traditional "intent" analysis and held that "a plaintiff in a university discrimination case need not prove intentional discrimination at every stage of the decisionmaking process; impermissible bias at any point may be sufficient to sustain liability."

${ }^{113}$ No. 89-00378, 1991 U.S. Dist. LEXIS 20572 (D. Haw. Aug. 13, 1991), rev'd in part, 40 F.3d 1551 (9th Cir. 1994).

$11440 \mathrm{~F} .3 \mathrm{~d}$ at 1558.

${ }^{115}$ Id. at 1560 . This supports the argument that one team member can have a serious impact on the ultimate decision. See infra notes $145-46$ and accompanying text (discussing the findings of industrial psychologists that group decision making is influenced by the social status of the advocating participants).

${ }^{116}$ See Lam, 40 F.3d at 1560 (describing Lam's evidence of discriminatory bias in the hiring process).

${ }^{117}$ See id. ("There was also evidence that another white male professor had stated that given Japanese cultural prejudices, the PALS [Pacific Asian Legal Studies] director should be male.").

${ }^{118} I d$. at 1560-61 (citing Roebuck v. Drexel Univ., 852 F.2d 715, 727 (3d Cir. 
Court's grant of the defendant's motion for summary judgment since a material issue of fact existed regarding whether there was a discriminatory motive for the employment decision. ${ }^{119}$

The Lam case is quite useful in enabling one to speculate whether a court, in finding that one member of a team has a prejudice against another team member or potential team member, would consider that finding sufficient to attach liability to the employer. Thus, if Lam is any indication, a court analyzing a Title VII claim based on a team decision would only require a plaintiff to show that one member of her team was prejudiced against her demographic group in order to establish liability. Such a result seems warranted in light of the ability of one prejudiced team member to exert powerful influence over the group's ultimate decision if she is held in high regard by a majority of the team. The Lam case, however, is not so helpful when no direct evidence of animus toward a protected group can be gathered, as is more frequently the case. To deal with those situations, courts have allowed the application of disparate impact analysis to subjective employment criteria. Courts have permitted claims of disparate impact that challenge subjective employment decisions to prevent employers from insulating themselves from Title VII liability by relying on the subjective evaluations of supervisors and middle management. The Supreme Court has noted:

[I]t may be customary and quite reasonable simply to delegate employment decisions to those employees who are most familiar with the jobs to be filled and with the candidates for those jobs. It does not follow, however, that the particular supervisors to whom this discretion is delegated always act without discriminatory intent. Furthermore, even if one assumed that any such discrimination can be adequately policed through

1988)); see also Fields v. Clark Univ., 817 F.2d 931, 933-35 (1st Cir. 1987) (holding that a female professor, who proved by direct evidence that unlawful discrimination motivated the University in denying her tenure, was not required to also prove that the discrimination was a "but for" cause). The Lam court further commented on the difficulty of establishing a claim of discrimination in the group context: "The university setting-in which, as in this case, employment decisions are made by a group, and collegiality and personal relationships are often significant factors-presents an especially difficult one in which to evaluate allegations of discrimination. As with all group decision making, a complex of motives may exist." Lam, 40 F.3d at 1564. The court's statement about faculty appointments is equally applicable to team-based decisions, which operate in similar ways.

119 See id. at 1554-55 (reversing the award of partial summary judgment and remanding for trial the plaintiff's claim of discrimination with regard to the 1987-1988 hiring search). 
disparate treatment analysis, the problem of subconscious stereotypes and prejudices would remain.

The Supreme Court sought to control the dissipation of Title VII claims under a disparate impact theory and to avoid forcing employers to validate the use of subjectivity in their evaluations by stressing the burdens of establishing a prima facie case. ${ }^{121}$ The Court went on to state:

It is self-evident that many jobs, for example those involving managerial responsibilities, require personal qualities that have never been considered amenable to standardized testing. In evaluating claims that discretionary employment practices are insufficiently related to legitimate business purposes, it must be borne in mind that " $[c]$ ourts are generally less competent than employers to restructure business practices, and unless mandated to do so by Congress they should not attempt it."122

Thus, while the Supreme Court gave plaintiffs who felt victimized by a subjective decision-making process an avenue for redress under Title VII, the Court left them to fight an uphill battle by giving much deference to employers' personnel decisions.

Subjective employment decisions, particularly in the group context, clearly raise some interesting problems in terms of regulation and proof under present Title VII law. The increased prevalence of team-based decision making in American companies will only exacerbate Title VII's present shortcomings in this regard. Neither present disparate treatment nor disparate impact jurisprudence provides ample opportunity for employees ostracized from the team system to have an adequate remedy. ${ }^{123}$ However, a reformulation of present Title VII law to account for this shift in the structure of American busi-

${ }^{120}$ Watson v. Fort Worth Bank \& Trust, 487 U.S. 977, 990 (1988). This statement acknowledges the Court's awareness of cognitive biases that can unconsciously influence a decision maker in reaching her ultimate decision. Lower courts have followed the Supreme Court's lead in acknowledging the potential for cognitive biases to infect an employment decision. See, e.g., Allen v. Seidman, 881 F.2d 375, 381 (7th Cir. 1989) ("[T] he danger [of administering tests devoid of objective standards] is acute that racial bias of which the testers may well be unconscious will influence the grade."); Stender v. Lucky Stores, Inc., 803 F. Supp. 259, 335 (N.D. Cal. 1992) ("[T] he court finds that Lucky's policy of leaving initial placement, promotion and training decisions to the sole discretion of lower level supervisors whose conscious and subconscious prejudices are unchecked by objective and publicized decision making criteria, has had a disparate impact....").

${ }_{121}$ See Watson, 487 U.S. at 993-94.

122 Id. at 999 (quoting Furnco Constr. Corp. v. Waters, 438 U.S. 567, 578 (1978)).

${ }^{123}$ See supra text accompanying note 28 (noting that Title VII law does not require a "grievance procedure for team members who feel that they have been treated unfairly"). 
ness operations, as Part V advocates, could effectively solve this deficiency in Title VII jurisprudence without opening the floodgates to frivolous claims.

\section{AN ALTERNATIVE TTILE VII ANALYSIS ACCOUNTING FOR THE NEW PRODUCTION MODEL}

The present Title VII framework does not adequately protect employees working under the new model of production, particularly, selfdirected work teams. Title VII was formulated on the premise that an individual decision maker may not take an employee's race, national origin, or sex into account at the moment an employment decision is made. ${ }^{124}$ As alluded to earlier, this presumption is deficient in three ways. First, Title VII analysis, under both disparate treatment and disparate impact theories, fails to account for many companies' use of enhanced employee participation in their workplaces, which has expanded the number of inputs into an employment decision. Second, the notion that an employer will state in some tangible way its animus toward a particular group is unlikely in today's more politically correct business society, making it more difficult for an employee to prove that she was discriminated against under the theory of disparate treatment. Finally, neither the disparate treatment nor disparate impact theories acknowledge the notion that an employer may not be conscious of a bias that has infected its decision-making process. ${ }^{125}$

Courts and legislators should take several steps to ameliorate the present shortcomings in Title VII law. Such steps would include: (i) requiring employers to articulate legitimate reasons for challenged employment decisions and to establish procedural safeguards to check for evaluator bias; (ii) imposing some form of liability on employers based on a showing that one decision maker among many took unlawful considerations into account; and (iii) permitting plaintiffs to point to the team system in general when making claims of disparate impact.

${ }^{124}$ See supra Part II (discussing the courts' traditional analysis of Title VII).

${ }^{125}$ See supra notes 49-58 and accompanying text (discussing the disparate impact theory as an alternative to the disparate treatment theory). 


\section{A. Elimination of the "Hicks Factor"}

First, the Hicks factor ${ }^{126}$ should be reversed for all Title VII cases. Hicks established that in the event a trier of fact finds that the employer's proffered rationale for the employment decision was pretextual, it may nonetheless deduce its own rationale for the decision in question, thus allowing the employer to escape liability. ${ }^{127}$ Based on the acceptance of cognitive bias theory by the Supreme Court, ${ }^{128}$ it is no longer reasonable to require a plaintiff to rebut the employer's offered rationales for its employment decision as well as any other reason that a trier of fact might adduce. If a trier of fact decides that the employer is being untruthful about its rationale for a particular employment decision after a plaintiff has satisfied his prima facie burden and shifted the burden of production to the employer, liability should attach. If an employer cannot articulate a credible reason, either objective or subjective, for the employment decision in question, it may well be the result of a decision infected by cognitive bias. Courts should recognize this as a violation of Title VII. It is not too onerous a burden to require that employers legitimize their decisions by offering lawful and legitimate reasons for their decisions, particularly when a plaintiff has satisfied her prima facie requirement. The inability to provide legitimate reasons raises a strong inference of discrimination, either blatant or cognitive, and should be unlawful under Title VII jurisprudence. This change-requiring the employer to offer lawful and legitimate reasons for its decision-will also diminish the impact of a judge or jury's cognitive bias since they will not be able to find a legitimate reason not proffered by the employer. Eliminating the Hicks factor will help ameliorate Title VII's failure to acknowledge cognitive bias without allowing a floodgate of frivolous litigation.

\section{B. The Establishment of Procedural Safeguards}

A federal statute also should require that employers utilizing forms of group decision making establish procedural safeguards to

${ }^{126}$ See supra notes $41-43$ and accompanying text (discussing the Hicks factor-that for an employer to be found guilty of discrimination, the trier of fact must affirmatively find that the employer's action was the product of unlawful discrimination).

${ }^{127}$ See supra note 43 and accompanying text (discussing the impact of the Hicks decision); see also Schallop v. New York Dep't of Law, 20 F. Supp. 2d 384, 401 (N.D.N.Y. 1998) ("The existence of factual questions whether defendants' stated reason was pretextual does not end the inquiry into pretext, however.").

${ }^{128}$ See supra note 120 and accompanying text (discussing the Court's recognition of cognitive bias in Watson v. Fort Worth Bank \& Trust, 487 U.S. 977 (1988)). 
prevent and catch an evaluator's bias toward a particular individual, particularly when the decisions involve a level of subjectivity. ${ }^{129}$ As discussed earlier, in both Woodson ${ }^{130}$ and $\mathrm{Lam}^{131}$ the employer failed to take such measures or to subject the employment decision in question to the measures that were established for that purpose. ${ }^{132}$ Procedural safeguards should involve several different processes in order to achieve their ultimate goal. One treatise has suggested:

Employers that must use subjective criteria as job requirements for positions that are not susceptible to objective description should construct their selection process carefully, keeping certain safeguards in mind. In implementing a selection process, any personal traits required should be expressed in writing as concretely as possible.... Furthermore, supervisors should be given specific written instructions on the application of any subjective elements used in evaluating personnel. The opinion of more than one supervisor should be solicited to minimize the chance of individual bias, and supervisory evaluations should be reviewed by higher management and by personnel or human resources staff. Finally, employees should be offered an opportunity to respond to supervisory evaluations, and an appeal procedure should be established for employees to contest evaluations.

1. Express Personal Traits in Writing and Give Instructions on How to Apply Subjective Elements Used in Evaluating Personnel

While many decisions reached by a self-directed work team are necessarily subjective, the employer should provide each individual team member with specific guidelines for assessing other team members. ${ }^{134}$ In order to make the evaluations more objective, employers should also list certain attributes that are essential for effective performance of a particular job because:

${ }^{129}$ See Krieger supra note 27, at 1285 (“[O]nly the application of deliberate, controlled, corrective processes can prevent stereotypes and subtle in group priming valences from biasing interpersonal judgment.").

109 F.3d 913 (3d Cir. 1997).

13140 F.3d 1551 (9th Cir. 1994).

132 See Woodson, 109 F.3d at 918 (discussing the employer's failure to adhere to company downsizing policies in terminating the plaintiff); Lam, $40 \mathrm{~F} .3 \mathrm{~d}$ at 1558 (noting that "guidance for the selection process was minimal").

133 45A AM. JUR. 2D, supra note $38, \S 419$.

194 See Krieger, supra note 27 , at 1286 (explaining that, in order to control the effects of unconscious bias, one must be aware of the process that can threaten one's judgment, motivated to correct its unwanted influence, able to discern the direction and magnitude of the bias, and have sufficient control over one's mental processes to correct the effect of unwanted influences). 
[E]xperimental evidence suggests that we can reduce stereotypic biases in evaluation when evaluative criteria are specifically identified and when we provide decision makers with a rich body of specific diagnostic information on which to base decisions. Stereotypic expectancies and other subtle forms of bias will have less influence in the evaluation process when decision makers apply less generalized, and more specific, preferably objective, criteria.

Under such a system, the evaluator would merely be required to give a specific numerical ranking on each attribute being considered. Employers should also provide evaluators with ample space to explain additional considerations which they believed were important in reaching their decision. Important attributes such as innate leadership qualities might not be specifically evaluated, but nonetheless might be worth mentioning to an employer. The key to an effective evaluation process is for an employer to explain both the dangers of cognitive bias and the aspects of the employer's system designed to minimize such behavior.

\section{A Review Process to Check for Outliers}

Employers should check for outliers in any particular employee's evaluation reports. Outliers are evaluations that are completely inconsistent with the team's general consensus about a particular employee's abilities. In such a case, the outlier raises an inference that the evaluator may have considered factors, other than those enumerated, in evaluating the employee in question. Each evaluator's opinion of a team member should be compared with other evaluations of that team member to uncover any significant discrepancies. In the event that outliers exist, the employer should exclude them in making its ultimate decision. If one team member's evaluation of a fellow team member appears to be so out of line with the rest of the group, it is likely the product of some form of bias.

\section{An Appeal Process}

All employees who are dissatisfied with a particular employment decision should have the right to appeal that decision. Many team structures already have some form of grievance procedure in place to maximize employee satisfaction. ${ }^{136}$ An appeal process will reduce the

${ }^{135}$ Krieger, supra note 27 , at $1329-30$.

${ }^{136}$ See supra note 28 (discussing certain teams' establishment of peer disciplinary committees). 
ultimate influence of cognitive bias by subjecting unfavorable employment decisions to further scrutiny. ${ }^{137}$ Challenged employment decisions that strike the reviewing committee as undeserved or erroneous should be overturned.

\section{Consequences of Failing to Establish Safeguards}

While establishing such safeguards may seem tedious and disruptive to the informality of the team process, such protections are necessary to control bias in major employment decisions. ${ }^{138}$ An employer that fails to employ such safeguards in a necessarily subjective employment decision should have the burden of proving that the employment decision in question was not tainted with unlawful considerations.

Thus, a plaintiff's claim of discrimination under Title VII should take into account whether the employer has established and utilized specific safeguards to catch and control incidents of discrimination by individual team members at the first stage in establishing a prima facie case. If the plaintiff satisfies the prima facie requirements and also demonstrates that the employer does not utilize the aforementioned safeguards, the burden of proof, not the burden of production as the law presently states, ${ }^{139}$ should shift to the employer to demonstrate that unlawful considerations were not part of this employment decision. However, if an employer has the necessary safeguards in place, and the plaintiff satisfies the prima facie test, only the burden of production should shift to the employer to articulate a non-

${ }^{137}$ See supra text accompanying note 62 (noting employers' use of an appeal process when utilizing subjective criteria in their personnel evaluations).

${ }^{199}$ Given the many minor decisions that are reached every day in the team model, it would be unduly burdensome to require that an employer subject every decision reached by the group to such a process. For important decisions, however, such as hiring, discipline, layoffs, evaluations, and promotions, such safeguards can be relatively easily implemented and utilized by employers to control unlawful bias on the part of individual team members. Many employers utilizing the team approach already employ some of these "safeguards." For example, in performing peer appraisals in teams, some employers have "each team member... evaluated by two team members, one of his or her choosing and one chosen by the rest of the team." YEATTS \& HYTEN, supra note 14, at 129. Employers utilizing self-directed work teams also have set up employee grievance committees to process allegations of improper or unfair team decisions. See supra text accompanying note 28 (discussing the suggestion by proponents of the team model to create some form of grievance procedure for team members who feel they have been treated unfairly).

${ }^{139}$ See supra notes 34-35 and accompanying text (explaining that, under current law, after a plaintiff has established a prima facie case, the burden of production shifts to the employer to articulate a non-discriminatory reason for the decision). 
discriminatory reason for the employment decision in question. In such a case, the burden of proof remains with the plaintiff. In light of the significant evidentiary difference between proving that discrimination did not occur in a given situation and merely proffering a nondiscriminatory reason for a decision, ${ }^{140}$ this reformulated legal analysis will provide liability-averse employers with significant incentives to establish mechanisms to control bias. ${ }^{141}$

\section{Imputing Partial Liability to an Employer When One Member of the Team Takes Unlawful Considerations into Account in Reaching an Employment Decision}

If a plaintiff can demonstrate that a particular team member discriminated against her, that too should be significant in attaching some form of liability to the employer under Title VII. Olson v. General Electric Astrospace stands for the proposition that if a supervisor takes unlawful considerations into account in reaching a particular employment decision, that decision can be imputed to the employer. ${ }^{142}$ This presumably stems from the fact that employers value the opinions of their supervisors, particularly ones who have firsthand knowledge of the requirements of a particular job or the attributes of a particular individual. ${ }^{143}$ That emphasis on particular, firsthand

${ }^{140}$ See supra notes 35-36 and accompanying text (discussing the difference between the burden of proof and the burden of production).

${ }^{141}$ The Supreme Court has previously provided employers with incentives to adopt certain employment practices in sexual harassment cases by providing employers with an affirmative defense in certain situations. See Burlington Indus., Inc. v. Ellerth, 524 U.S. 742, 765 (1998) (holding that “[w] hen no tangible employment action is taken, a defending employer may raise an affirmative defense to liability or damages, subject to proof by a preponderance of the evidence" (citation omitted)). To raise an affirmative defense to a claim of sexual harassment, the employer must demonstrate that he "exercised reasonable care to prevent and correct promptly any sexually harassing behavior." Id. He must also show that the plaintiff "unreasonably failed to take advantage of any preventive or corrective opportunities provided by the employer. ${ }^{n} I d$. While not dispositive of the first prong of the defense, an employer's implementation of an "antiharassment policy with complaint procedure ... may appropriately be addressed in any case when litigating the first element of the defense." Id. In addition, an employer's demonstration that the plaintiff failed to utilize a complaint procedure provided by the employer "will normally suffice to satisfy the employer's burden under the second" prong. Id.

${ }^{142}$ See Olson v. General Elec. Astrospace, 101 F.3d 947, 955 (3d Cir. 1996) (noting that "[w]here a hiring decision is based largely or entirely on a recommendation or evaluation made by an employee who perceived the applicant as disabled, the employer can be held liable in a perception case"); see also supra note 72 and accompanying text (discussing the Olson case).

${ }_{143}$ See id. at 954-55 (noting that the supervisor in question had previously worked 
knowledge holds true in the team context and may even be more dramatic due to the close professional and personal relationships that often are formed within the team structure. ${ }^{14}$ Industrial psychologists have documented that group decision making is influenced by the social status of the members advocating a particular position. ${ }^{145}$ Thus, if a particular team member enjoys an elevated status within the group, that team member's opinion can be quite influential in the ultimate group decision. ${ }^{146}$ Therefore, the potential influence of a single member on a particular decision can be as great as if it had come from a direct supervisor.

Accordingly, if it is proven that a team member allowed unlawful considerations to bias his decision, liability should be imputed to the employer. Once a plaintiff demonstrates that a team member has taken unlawful considerations into account in forming her decision, the employer can raise a partial affirmative defense by demonstrating that she would have reached the same decision regardless of the unlawful consideration, according to the law presently set forth in the Civil Rights Act of $1991 .^{147}$ Thus, in such a scenario, the court should still be authorized to grant declaratory relief, injunctive relief, and attorney's fees and costs incurred as a result of the litigation. This proposal does not advocate for a dramatic change in the law; it merely clarifies the idea that when a plaintiff demonstrates that one of her team members took unlawful considerations into account in reaching her decision, the burden of proof shifts to the employer to show that the same decision would have been reached despite the unlawful considerations. The input of one discriminatory team member therefore should be enough to establish that discrimination was a motivating

\footnotetext{
with the plaintiff and was aware of his mental condition).

${ }^{144}$ See supra notes 118-19 and accompanying text (discussing the Ninth Circuit's acknowledgement of the impact that a biased decision maker can have in an intimate group decision-making context).

See, e.g., Charlan Jeanne Nemeth, Minority Dissent as a Stimulant to Group Performance, in GROUP, PROCESS AND PRODUCTIVITY 95, 97 (Stephen Worchel et al. eds., 1992) (discussing the power of the majority in group decision making even when the majority is wrong); YEATTS \& HYTEN, supra note 14, at 92-95 (discussing the phenomenon of "groupthink" and how decision making is affected by group dynamics).

${ }^{145}$ See Barenberg, supra note 6, at 907 (noting the problems that result when "team members flee responsibility by becoming dependent on a charismatic or domineering team member or leader").

${ }^{147} 42$ U.S.C. $\$ 2000 \mathrm{e}-5(\mathrm{~g})(2)$ (B)-(i) (1994) (giving the court authority to grant declaratory relief, injunctive relief, and attorney's fees and costs if a plaintiff can demonstrate that unlawful considerations played a part in the employer's decision but the employer is able to show that he "would have taken the same action in the absence of the impermissible motivating factor").
} 
factor in the decision being challenged. The availability of relief is necessary because it is too speculative to say whether a particular outcome would have occurred without the influence of particular advocates. That only one team member held discriminatory animus toward another individual does not mean that other team members were not influenced in some capacity by the discriminating individual.

\section{Lenient Application of the "Aggregation Concept" in Claims of Disparate Impact}

Finally, courts should be lenient with plaintiffs who attempt to demonstrate a prima facie case of disparate impact involving subjective, team-based decisions. The initial burden is on the plaintiff to "demonstrate that each particular challenged employment practice causes a disparate impact." ${ }^{\text {148 }}$ However, the Civil Rights Act of 1991 modified the analysis somewhat by stating that "if the complaining party can demonstrate to the court that the elements of a respondent's decision-making process are not capable of separation for analysis, the decision-making process may be analyzed as one employment practice."149 Courts have struggled with how to apply this provision of the Act, with some applying the aggregation concept loosely and others taking a much more stringent approach. ${ }^{150}$ Despite the present lack of uniformity in its application, courts should apply the Act's aggregation concept loosely in the team context, particularly when dealing with challenges to subjective decisions. Otherwise, it is exceedingly difficult for plaintiffs to effectively challenge the applica-

${ }^{148} 42$ U.S.C. $\$ 2000 \mathrm{e}-2(\mathrm{k})(1)$ (B) (i) (1994); see also supra notes $49-58$ and accompanying text (discussing the plaintiff's burden in claims of disparate impact).

${ }_{149} 42$ U.S.C. $\$ 2000 \mathrm{e}-2$ (k) (1) (B) (i).

${ }^{150}$ Compare, e.g., Butler v. Home Depot, Inc., Nos. C-94-4335SI, C-95-2182 SI, 1997 WL 605754 , at $* 13$ (N.D. Cal. Aug. 29, 1997) (stating that the defendant's system of delegating hiring, pay, job assignment, and promotion decisions to store managers is incapable of separation for analysis), and Association of Mexican-Am. Educators v. California, 937 F. Supp. 1397, 1408 (N.D. Cal. 1996) (treating three subparts of an examination as a single practice), amended and superseded by 1999 WL 976720 (9th Cir. 1999), and Stender v. Lucky Stores, Inc., 803 F. Supp. 259, 335 (N.D. Cal. 1992) (finding that the defendant's "subjective and ambiguous decision making processes are not separable for the purposes of analysis, and therefore may be analyzed as one employment practice"), with Johnson v. Uncle Ben's, Inc., 965 F.2d 1363, 1367 (5th Cir. 1992) (finding that plaintiffs failed to satisfy their prima facie burden because they did not perform a "systematic analysis of the racial effects of all promotional criteria for each rank" (citation omitted)), and Appleton v. Deloitte \& Touche L.L.P., 168 F.R.D. 221, 225-26 (M.D. Tenn. 1996) (denying class certification to plaintiffs challenging an employer's use of subjectivity in making employment decisions for failing to demonstrate a breakdown of each personnel decision). 
tion of team-based decision making because it is unlikely that a plaintiff can demonstrate a significant statistical disparity if she is only challenging a micro-aspect of the team process due to the lack of similarly situated team members.

For example, in Butler v. Home Depot, Inc., "female employees and applicants throughout Home Depot's West Coast Division, allege[d] gender discrimination by Home Depot in hiring, initial assignments, promotions, compensation and training." ${ }^{\text {,51 }}$ Home Depot moved for summary judgment, claiming that plaintiffs' disparate impact claims must fail because they have failed to identify specific employment practices causing the alleged disparate impact. ${ }^{152}$ Plaintiffs' sociological expert, Dr. Bielby, summarized Home Depot's personnel system as follows:

[I]t is the policy of Home Depot to delegate decisions about hiring, pay, job assignment, and promotions to Store Managers or teams of managers who, individually and as a team, base those decisions on their own subjective judgments with virtually no written criteria for systematically evaluating the qualifications of individual candidates. ${ }^{153}$

The court was satisfied, based on the aforementioned evidence, that Home Depot's personnel decision-making process was incapable of separation for analysis and could be challenged as one employment practice. ${ }^{154}$ The facts of Home Depot and its rationale provide a close analogy for a disparate impact claim brought by a disgruntled team member or group of team members.

In order for a protected employee to have any hope of prevailing on a valid claim of disparate impact, she will have to attack the entire concept of autonomous work teams. Teams are too small to make a more individualized claim with any statistical support. For example, an African-American male team member will not be able to support his claim that the team assignment system-assigning members' tasks within the production process-is discriminatory if there are only a few African-American men on the team, all of whom have been assigned different roles. A disgruntled team member should be permit-

${ }^{151}$ Nos. C-94-4335 SI, C-95-2182 SI, 1997 WL 605754, at *1 (N.D. Cal. Aug. 29, 1997).

${ }_{152}$ See id. at *13 (noting Home Depot's argument that the four employment practices are capable of separation and therefore "plaintiffs must identify discrete employment practices by Home Depot that adversely impact female employees").

${ }^{153}$ Id. at *13.

154 See id. ("Having reviewed the evidence in this matter, the Court is satisfied that the elements of Home Depot's decisionmaking process are not capable of separation for analysis."). 
ted to rely on statistics from other teams within the company to demonstrate the discriminatory impact of the employment practice. When analyzing the team structure from the perspective of the company as a whole, plaintiffs will have a greater chance of demonstrating a significant disparity between their protected class and the rest of the demographic groups within the team system.

In drafting the Civil Rights Act of 1991, Congress stated: "When a decision making process includes particular, functionally-integrated practices which are components of the same criterion, standard, method of administration, or test,... the particular, functionallyintegrated practices may be analyzed as one employment practice. ${ }^{\text {155 }}$ A particular employee's opportunities for advancement, job stability, and work assignments are all determined by his autonomous work team. Thus, the employment practice of placing a great deal of autonomy in a team's control is a "functionally-integrated" practice, and courts should apply the Act's aggregation concept leniently. The African-American employees from S.C. Johnson, for example, should be able to establish their prima facie claim of disparate impact by showing that the employer's reliance on team work has hindered opportunities for all African Americans in the manufacturing plant, provided that the plaintiffs can statistically support their claim. At this point, the burden of proof would shift to S.C. Johnson to show that the team-based structure is a business necessity. Under this scenario, the employer would still have the chance to prove that the autonomy of teams significantly improves its productive capabilities, a notion well supported by industrial psychologists. The plaintiffs, however, are at least afforded an opportunity to proffer a readily available, nondiscriminatory alternative to the challenged practice. If courts apply the Act's aggregation concept strictly, plaintiffs will rarely have the opportunity to offer an effective alternative to the aspect of the team system that is causing the challenged impact.

\section{CONCLUSION}

"The most comprehensive cross-national industrial study ever undertaken (MIT's worldwide auto study) predicts confidently that the Japanese model of team production is applicable to every industry in all countries and is destined to 'become the standard global production system of the twenty-first century. ${ }^{\$ 156}$ The growing movement

155137 CONG. REC. S 15273-01 (daily ed. Oct. 25, 1991).

${ }^{156}$ Barenberg, supra note 6, at 927 (quoting JAMES P. WOMACK ET AL., THE 
within American companies to expand employee participation through the use of work teams raises interesting challenges to the structure of Title VII analysis. Moreover, the increased reliance on subjective employment decisions continues to provoke interesting questions and concerns. The Supreme Court's acknowledgment of the potential for cognitive biases against protected groups only further complicates the way in which an aggrieved employee must go about proving Title VII claims under either the disparate treatment or disparate impact theories.

Yet, there are ways to reform the present system to better eliminate the various forms of prejudicial animus which Title VII was enacted to prevent. Eliminating the Hicks factor in Title VII jurisprudence, establishing procedural safeguards to minimize evaluator bias, providing employers with only a partial affirmative defense when a plaintiff demonstrates that one of his team members considered that employee's race, national origin, or sex in reaching their decision, and applying the Civil Rights Act of 1991's aggregation concept loosely in claims of disparate impact will make Title VII more functional, in light of the recent team trend in American companies.

Some of these reforms, such as the elimination of the Hicks factor, are long overdue. Others, like requiring procedural safeguards, are more controversial and have the potential of significantly altering employers' litigation strategies. All of these suggested reforms, however, are necessary in light of the level of insulation that employers presently enjoy under Title VII given the increased prevalence of subjective, group decision making. These reforms are certainly not the only ways in which to address and potentially resolve the shortcomings of Title VII law, but they do offer an effective starting point. 
$* * * * * * * \begin{array}{llll}* & * & *\end{array}$ 